BULLETIN OF POLTAVA
STATE AGRARIAN
$\begin{aligned} & \text { ACADEMIV } \\ & \text { medicine }\end{aligned}$
original article | UDC 636.09:636.7:616-006 | doi: 10.31210/visnyk2020.02.22

SPREADING AND TREATMENT OF DOGS' TISSUE GROWTH PATHOLOGY

\author{
N. I. Dmytrenko* \\ ORCID (DD 0000-0001-5336-2361 \\ L. M. Sherstiuk \\ ORCID (D) 0000-0003-0229-464X
}

Poltava State Agrarian Academy, 1/3, Skovorody str., Poltava, 36003, Ukraine

*Corresponding author

E-mail: nadiya.dmytrenko@ gmail.com

How to Cite

Dmytrenko, N. I., \& Sherstiuk, L. M. (2020). Spreading and treatment of dogs' tissue growth pathology. Bulletin of Poltava State Agrarian Academy, (2), 179-186. doi: 10.31210/visnyk2020.02.22

The spreading of tumors among dogs and cats in the town of Poltava was analyzed. In order to determine the spreading of neo-formations among dogs and cats, statistical data for the last two years were collected and processed in veterinary clinics of Poltava. Differential diagnostics of morphological types of some kinds of dog tumors was conducted. Morphological, cytological and histological structure of neoplasms was considered. The problem of tumor growth is quite common among small dogs and cats. For the last two years, tumors were diagnosed in 98 dogs and 77 cats (56\% and 44\%, respectively). Among dogs, $70 \%$ of them were purebred. But a significant predisposition to tumors of certain types in a particular breed was not revealed. In most cases, (21.4\%) dogs were diagnosed with malignant mammary gland tumors. Those tumors were of different sizes and spread over one or more milk packets. Papillomatosis (18.4\%) is a quite common pathology of tissue growth. The places of localization and placement of papillomas on the body of dogs and cats were outlined, and description of their appearance was given. The order of tumor germ formation was characterized. Depending on the symptoms and course of the disease, such diagnostic methods as palpation, radiography, ultrasound diagnostics were used, and in some cases morphological and biochemical parameters of blood were examined to determine the degree of metabolic disorders. Not only tumor was locally studied but also the degree of involvement of the surrounding tissues in pathological process. The reaction of local lymphatic nodes and the appearance and development of metastases were monitored with the help of ultrasound diagnostic device. Different treatment regimens of experimental animals' papillomatoses were compared. It has been found out that including "Vincristine" preparation to the treatment regimen significantly reduces the term of treatment and gives the expressed therapeutic effect after the second injection, which results in gradual reduction of papillomas, their drying and rejection.

Key words: tumor, neoplasms, histological examination, chemotherapy, tumor morphology.

\title{
ПОШИРЕНІСТЬ ТА ЛІКУВАННЯ ПАТОЛОГІЇ ТКАНИННОГО РОСТУ В СОБАК
}

\section{Н. І. Дмитренко, Л. М. Шерстюк}

Полтавська державна аграрна академія, м. Полтава, Україна

Проаналізовано розповсюдження пухлин серед собак $і$ котів м. Полтави. 3 метою визначення поширеності новоутворень серед собак та котів було зібрано й оброблено статистичні дані по клініках ветеринарної медицини м. Полтави за останні два роки. Проведено диференційну діагностику морфологічних типів деяких видів пухлин у собак. Розглянуто морфологічну, ичитологічну та гістологічну будову новоутворень. Проблема пухлинного росту є досить поширеною у собак та котів. 3 а останні два роки новоутворення діагностували у 98 собак та 77 кімок (56\% та 44 \% відповідно). 


\title{
ВЕТЕРИНАРНА МЕДИЦИНА
}

Серед собак 70 \% були породистими. Але достовірної схильності до пухлин певного виду у якоїсь окремої породи не виявлено. Щонайбільше (21,4\%) у собак діагностували злоякісні пухлини молочної залози. Вони мали різний розмір і охоплювали один або кілька молочних пакетів. Досить поширеною патологією тканинного росту є папіломатоз (18,4\%). Окреслено місия локалізаиї та розміщення папілом на тілі собак та котів, а також подано опис їх зовнішнього вигляду. Охарактеризовано порядок формування пухлинного зачатку. Залежно від симптоматики та перебігу захворювання використовували такі методи діагностики, як пальпація, рентгенографія, ультразвукова діагностика, інколи проводили дослідження морфологічних і біохімічних показників крові з метою виявлення ступеня порушення обміну речовин. Місиево досліджували не лише саму пухлину, а і ступінь втягнення 8 патологічний прочес оточуючих тканин. За допомогою апарату для ультразвукової діагностики слідкували за реакиією ретіонарних лімфатичних вузлів та за появою і розвитком метастазів. Порівняно різні схеми лікування папіломатозів піддослідних тварин. Встановлено, що включення у схему лікування препарату «Вінкристин» значно скорочує термін лікування та дає виражений терапевтичний ефект вже після другої ін'єкиії, щзо забезпечує поступове зменшення папілом, їх зсихання та відторгнення.

Ключові слова: пухлина, новоутворення, гістологічні дослідження, хіміотерапія, морфологія пухлин.

\section{РАСПРОСТРАНЕННОСТЬ И ЛЕЧЕНИЕ ПАТОЛОГИИ ТКАНЕВОГО РОСТА У СОБАК}

\author{
Н. И. Дмитренко, Л. Н. Шерстюк
}

Полтавская государственная аграрная академия, г. Полтава, Украина

Проанализировано распространение опухолей среди собак и котов г. Полтавы. С целью определения распространения новообразований среди собак и кошек было собрано и обработано статистические данные в клиниках ветеринарной медицины г. Полтавы за последние два года. Установлено, что проблема опухолевого роста достаточно распространена среди собак и кошек. $B$ период 2018-2020 годов новообразования диагностировали у 98 собак и 77 кошек (56\% и $44 \%$ соответственно). Среди собак $70 \%$ были породистыли. В большинстве случаев $(21,4 \%)$ у собак диагностировали злокачественные опухоли молочной железы. Достаточно распространенной патологией тканевого роста является папиломатоз (18,4\%). В статье проведено сравнение разных схем лечения папиломатозов у подопытных животных. Установлено, что включение в схему лечения препарата «Винкристин» значительно сокращает срок лечения и дает выраженный терапевтический эффект уже после второй инъекции, что обеспечивает постепенное уменьшение папилом, их усыхание $u$ отторжение.

Ключевые слова: опухоль, новообразование, гистологические исследования, химиотерапия, морфология опухолей.

Вступ

Проблема пухлинного росту цікавить широке коло науковців різноманітних напрямів, а її вивчення у тварин, зокрема в собак, має вагоме теоретичне і практичне значення.

Пухлини для організму є патологічним процесом. При патології тканинного росту внаслідок змін у генетичному апараті трансформованих клітин виявляють надмірний, некоординований 3 макроорганізмом ріст тканин, спостерігається безконтрольний поділ клітинних структур, порушуються процеси росту та диференціації тканини [1-3]. У разі доброякісних пухлин виникає тканинний, а при злоякісних пухлинах і клітинний атипізм, що різко відрізняє пухлинну тканину від нормальної. На відміну від проліферації клітин, при фізіологічних процесах, таких як регенерація, інкапсуляція та інші захисно-пристосувальні реакції організму, пухлинний ріст завжди має патологічний характер і негативно впливає на стан організму загалом. Пухлини можуть розвиватися в будь-якій тканині та органі організму [1, 4-13].

Пухлини у дрібних домашніх тварин мають різну форму і структуру, але при цьому вони мають спільні закономірності росту і клінічного прояву та впливу на організм. Поряд з цим патогенез змін в організмі при пухлинному рості $є$ маловивченим. Наразі у ветеринарній медицині реалізуються спільні проєкти з гуманною медициною щодо проведення досліджень, розроблення й успішного застосування нових методів лікування патології тканинного росту. Для обгрунтованого встановлення діагнозу на онкологічне захворювання необхідно використовувати такий алгоритм дій: 


\section{ВЕТЕРИНАРНА МЕДИЦИНА}

1. Визначити патологію тканинного росту;

2. Провести загальне обстеження зміненої тканини та органу;

3. Встановити наявність метастазів;

4. Провести мікроскопічні дослідження зміненої тканини та встановити гістологічне походження пухлини і ступінь анаплазії [1, 14-19].

У деяких закордонних клініках ветеринарної медицини, крім класичних методів, таких як хірургічне видалення пухлин та хіміотерапія, почали застосовувати променеву терапію новоутворень. Найчастіше ії використовують для лікування пухлин з високою вірогідністю агресивної місцевої інфільтрації та вростання. Променева енергія впливає локалізовано і може застосовуватися для пухлин, які не були повністю видалені (наприклад, саркоми м'яких тканин), для терапії деяких пухлин головного мозку, або для покращення якості життя при таких високометастатичних пухлинах як остеосаркома $\mathrm{i}$ злоякісна меланома $[2,20]$.

Метою дослідження було з'ясувати поширеність пухлин серед собак міста Полтави, інформативності інструментальної та спеціальної клініко-лабораторної діагностики новоутворень і пошук ефективної схеми лікувальних заходів. Серед завдань досліджень - визначення співвідношення різних видів пухлин у собак і котів та порівняння ефективності препаратів «Вінкристин» та «Фітоеліта Метастоп» для лікування папіломатозів.

\section{Матеріал і методи досліджень}

Роботу виконували впродовж 2018-2019 років. Поширення новоутворень у собак та котів вивчали за даними звітної документації лікарень та клінік ветеринарної медицини (журнали амбулаторного прийому тварин) м. Полтави. Зокрема в Полтавській міській державній лікарні ветеринарної медицини, клініці ветеринарної медицини «VetExpert», клініці ветеринарної медицини, що функціонує на базі кафедри терапії імені професора П. І. Локеса Полтавської державної аграрної академії, клініці ветеринарної медицини «VetHelp». Дослідження за допомогою апарату УзД проводили у клініці ветеринарної медицини «VetExpert» та клініці ветеринарної медицини кафедри терапії імені професора П. І. Локеса Полтавської державної аграрної академії.

Предметом дослідження були собаки з патологічним тканинним ростом та гістологічні зразки пухлини. Розглядали морфологічну, цитологічну та гістологічну будову новоутворень. Гістологічні дослідження проводили на базі патолого-анатомічного відділу Полтавської обласної лікарні згідно із загальноприйнятою методикою $[1,16,21]$.

Під час проведення хіміотерапій при множинних папіломатозах ми вирішили порівняти терапевтичну ефективність двох препаратів: «Вінкристин» і «Фітоеліта Метастоп». Для цього було сформовано дві групи тварин за принципом аналогів. Для лікування обох груп тварин застосовували «Ессенціалє» (внутрішньо по 1 капсулі 3 рази на день, від 14 днів до 3-х місяців), «Катозал» (підшкірно 1 мл/10 кг ваги 1 раз на день, 10 днів), «Тіопротектин» (підшкірно по 1мл /10 кг ваги 2 рази на день, 10 днів). Крім цього до схеми лікування собак першої дослідної групи включили «Вінкристин», який вводили внутрішньовенно, повільно (від 30 хвилин до 2-х годин), 1 мл/30 кг ваги, 1 раз на сім днів, 4 рази, а другої групи - таблетки «Фітоеліта Метастоп», які містять у своєму складі біологічноактивні речовини рослинного походження (внутрішньо 1 таблетка /10 кг 3 рази на день, курсами по 4-5 днів, кожні 3-4 місяці). Тривалість лікування в різних тварин була різною і коливалася від декількох тижнів до декількох місяців. Протягом усього періоду лікування за тваринами вівся нагляд та моніторинг клінічного стану.

\section{Результати досліджень та їх обговорення}

3 метою визначення поширеності новоутворень серед собак та котів було зібрано і оброблено статистичні дані за останні два роки по лікарнях ветеринарної медицини м. Полтави. Найчастіше різні види патології тканинного росту реєстрували в Полтавській міській державній лікарні ветеринарної медицини. Протягом 2018-2019 років до них звернулося 119 господарів собак і котів зі скаргами на пухлинні розростання у їхніх домашніх улюбленців. Серед піддослідних тварин було зафіксовано 77 випадків у собак та 42 випадки в котів. У клініці ветеринарної медицини «VetExpert» за аналогічний період було зареєстровано 44 звернення власників дрібних домашніх тварин з різними новоутвореннями (зафіксовано 12 випадків у собак та 32 - у котів). У клініці ветеринарної медицини, що функціонує на базі кафедри терапії імені професора П. І. Локеса Полтавської державної аграрної академії протягом 2018-2019 років зафіксовано 8 випадків патологічного розростання тканин у домашніх тва- 


\section{ВЕТЕРИНАРНА МЕДИЦИНА}

рин. Серед них 6 собак та 2 кішки. Протягом останніх двох років у клініці ветеринарної медицини «VetHelp» було зареєстровано лише чотири випадки новоутворень (3 собаки та 1 кішка).

Аналізуючи журнали амбулаторного прийому тварин у ветлікарнях міста Полтави, можна зробити висновок, що проблема новоутворень серед дрібних домашніх тварин досить поширена. Загалом за останні два роки патологію тканинного росту було зареєстровано у 98 собак та 77 котів (що становило $56 \%$ та $44 \%$ від усіх зареєстрованих випадків відповідно). $70 \%$ собак з новоутвореннями були породистими, а $30 \%$ безпорідні. Проте достовірної схильності до патології тканинного росту в якоїсь певної породи встановлено не було.

Досліджуючи безпосередньо хворих собак, морфогенез патології тканинного росту можна розділити на дві стадії: передпухлинних змін та формування і розростання пухлини. До передпухлинних змін можна віднести такі фонові зміни тканин, як дистрофія, атрофія та склероз, метаплазія, дисплазія та гіперплазія клітин.

Формування та розвиток пухлини відбувається за такою схемою:

- порушення процесу регенерації;

- виникнення передпухлиних змін у вигляді дисплазії та гіперплазії;

- виникнення малігнізації клітин, які діляться;

- $\quad$ утворення пухлинного зачатку та подальша прогресія пухлини.

Згідно $з$ даними журналів амбулаторного прийому тварин у собак найчастіше були зареєстровані новоутворення молочної залози (21,4 \% зареєстрованих випадків), зазвичай, злоякісного характеру. Вони були різного розміру, могли охоплювати один або кілька молочних пакетів (рис. 1, 2).

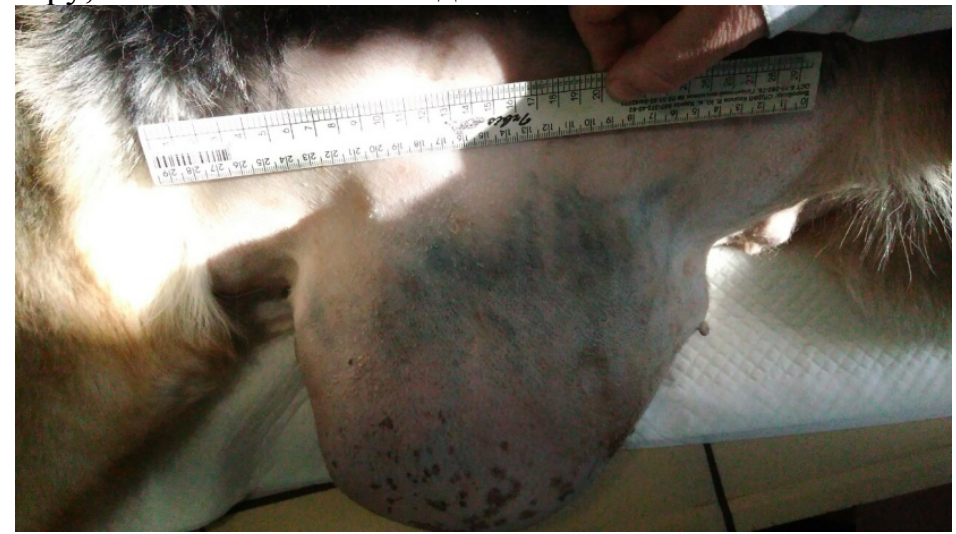

Рис. 1. Пухлина молочної залози в німецькой вівчарки

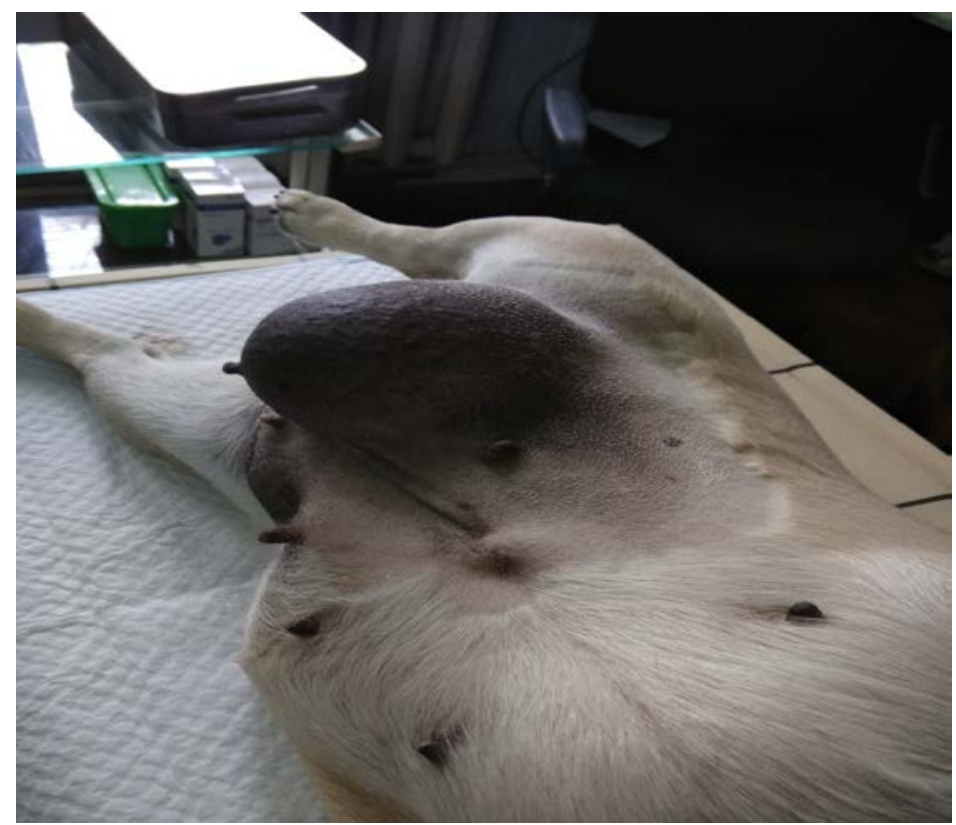

Рис. 2. Пухлина молочної залози в собаки породи мопс 


\section{ВЕТЕРИНАРНА МЕДИЦИНА}

На другому місці за поширеністю знаходиться папіломатоз (18,4 \% зареєстрованих патологій тканинного росту). Папіломи виявляли на різних ділянках тіла, найчастіше на вухах, животі, в ділянці рота та очей. Розташовувались папіломи поодиноко чи групами, могли кріпитися тонкою ніжкою або широкою основою. Поверхня папілом частіше зерниста та нагадує цвітну капусту, але траплялися й гладенькі види. Під час мікроскопічного дослідження гістологічних препаратів папілом виявляли, що сосочковий шар шкіри був потовщений, реєстрували значне розростання строми шкіри, яка згори вкрита плоским багатошаровим епітелієм.

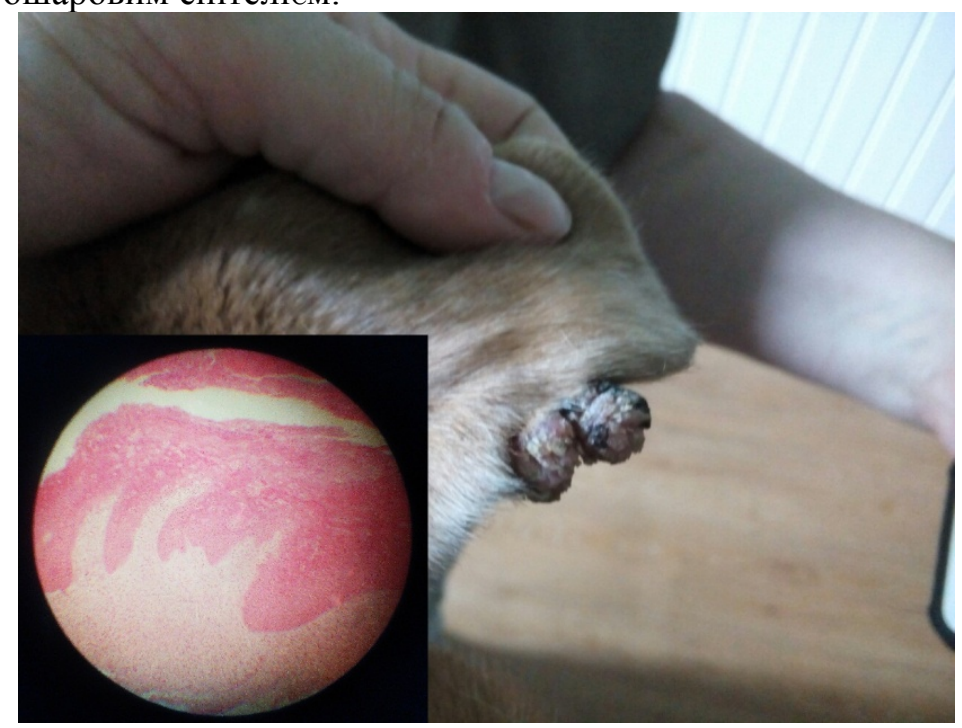

Рис. 3. Папіломи в собаки в ділянці вуха та ӥх гістологічна картина у збільщенні 7 × 40, фарбування гематоксиліном та еозином

Третє місце за рівнем поширення новоутворень серед собак міста Полтави займають ліпоми (12,2 \% від зареєстрованих випадків). Саркому було виявлено лише у 8,2 \% тварин, аденому простати - у 7,1 \% та остеому - у 6,1 \%. По 5,1 \% від загальної кількості звернень встановлювали діагноз на атерому, карциному та фіброму, і по 3 \% - гемангіому та меланому. Меланома розвивається з клітин епідермісу, які містять меланоцити і виробляють меланін. Найчастіше вражається шкіра, на якій спостерігають чорні вузли. При мікроскопічному дослідженні гістологічних препаратів у шкірі знаходять овальні і веретеноподібні клітини. У меланоцитах добре видно пігмент меланін від темнокоричневого до чорного кольору (рис. 4).

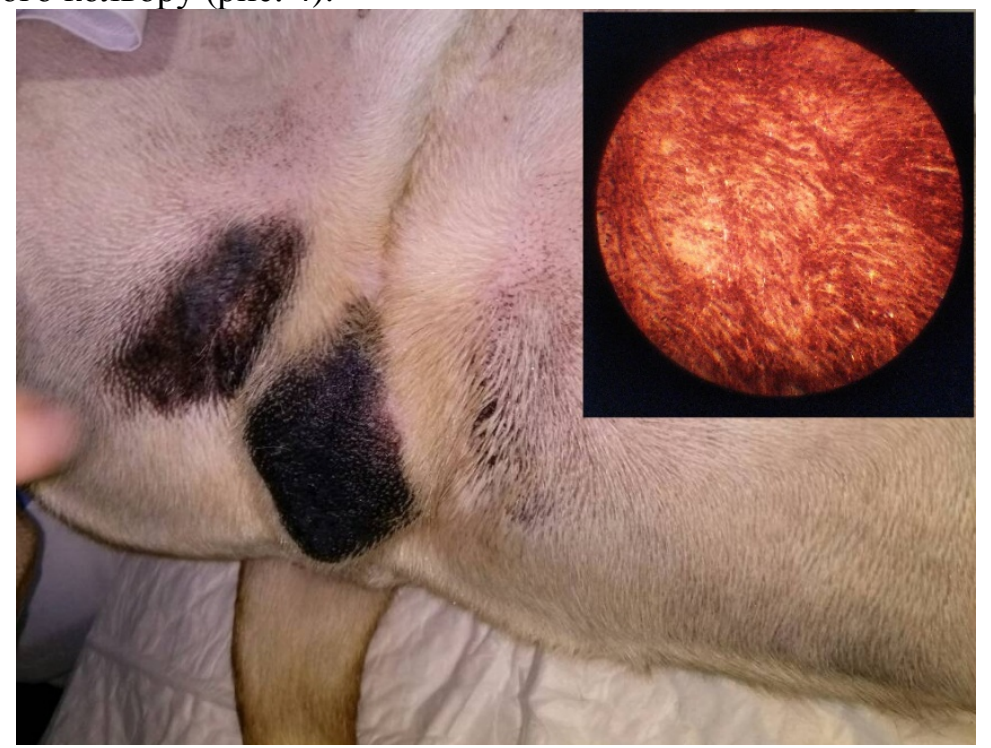

Рис. 4. Меланоми в собаки породи американський стафордщирський тер'єр у ділянці паху та статевих губ та їх гістологічна картина у збільщенні $7 \times 40$, фарбування гематоксиліном та еозином 


\section{ВЕТЕРИНАРНА МЕДИЦИНА}

Ангіоми є пухлинними розростаннями з кровоносних і лімфатичних судин. Вони можуть виникати в різних органах і частинах тіла, мати різні розміри та форму (рис. 5).

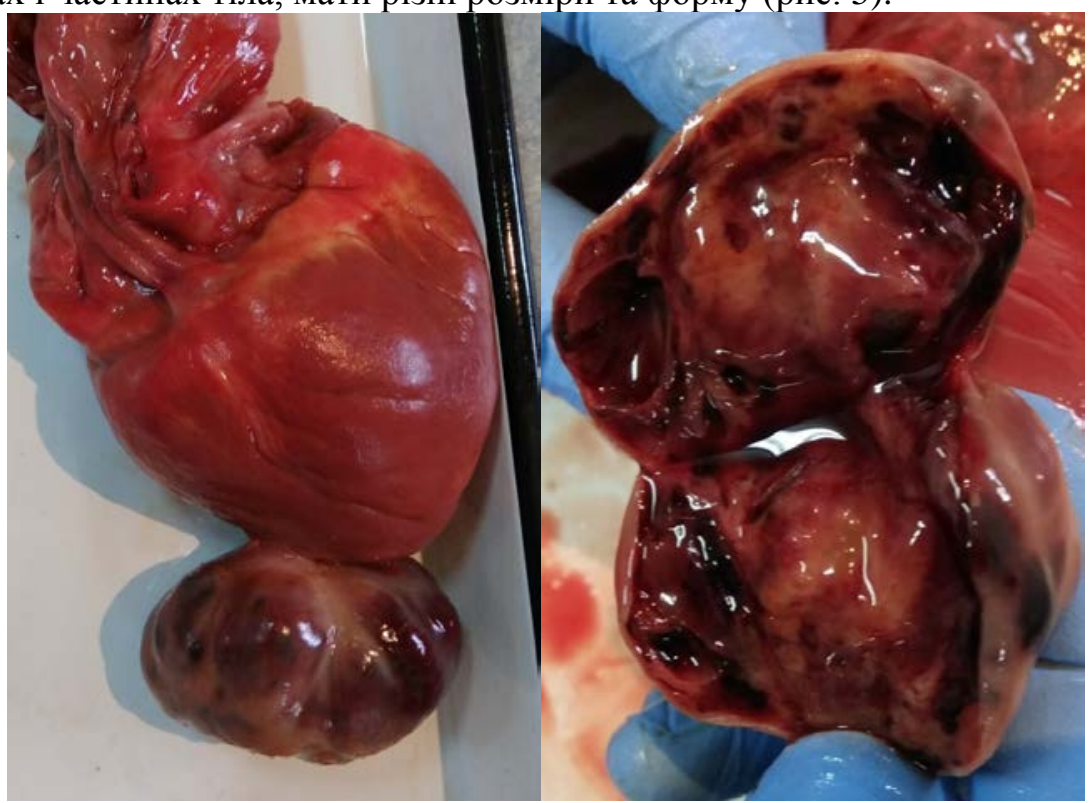

Рис. 5. Ангіома на серці німецької вівчарки віком 7 років

Інші види пухлин траплялися рідко і загалом становили близько $5 \%$ від усіх зареєстрованих випадків.

Собак, у яких було виявлено патологію тканинного росту, піддавали повному обстеженню. Залежно від симптоматики та перебігу захворювання використовували такі методи діагностики, як пальпація, рентгенографія, ультразвукова діагностика. В деяких випадках проводили дослідження морфологічних і біохімічних показників крові з метою виявлення ступеня порушення обміну речовин. Місцево досліджували не лише саму пухлину, а й ступінь втягнення в патологічний процес оточуючих тканин. Використання апарату для ультразвукової діагностики дало змогу прослідкувати за реакцією регіонарних лімфатичних вузлів та за появою і розвитком метастазів. Мікроскопічно проводили дослідження гістологічних препаратів, які були виготовлені після хірургічного видалення пухлин.

Рішення про подальше лікування тварини ухвалювали спільно з власником лише після остаточного встановлення діагнозу і визначення типу пухлини. Брали до уваги такі критерії, як тип пухлини, іiі величину та місце локалізації, поширення та ступінь розвитку метастазів. Одним з головних факторів був подальший прогноз комфортності життя собаки. За можливості проводили хірургічне видалення пухлини, а при множинних пухлинах і папіломатозах - застосовували хіміотерапію. Препарати для хіміотерапії зупиняють розмноження і функцію клітин, цим самим безпосередньо впливають на пухлину $[13,14]$. Але необхідно зважати на те, що ці препарати також впливають на функцію і життєдіяльність здорових клітин організму, особливо тих, які активно діляться.

3'ясування та уточнення патогенезу патології тканинного росту у дрібних домашніх тварин має велике значення як для наукових досліджень, так і для практикуючих лікарів ветеринарної медицини.

Виокремлюють певні відмінності між доброякісними і злоякісними пухлинами. Доброякісні пухлини зазвичай складаються зі зрілих диференційованих клітин $[14,20]$. Під час гістологічного дослідження і макроскопічного огляду такої пухлини можна визначити вид тканини, з якої вона утворилася. Такі пухлини ростуть експансивно, тобто вони відмежовані від тканин організму своєрідною капсулою, і збільшуючись, розсовують оточуючі тканини, не руйнуючи їх. Оскільки доброякісні пухлинні клітини не виділяють специфічних лізуючих речовин, вони не можуть зруйнувати стінки кровоносних судин, що робить майже неможливим процес інтравазації пухлинних клітин та виникнення метастазів. Злоякісні пухлини складаються з мало диференційованих або взагалі недиференційованих клітин. Ці пухлини ростуть інфільтративно (інвазивно) - пухлинні клітини проникають в оточуючі тканини і пухлина немов вростає у тканину $[9,11]$. Унаслідок цього оточуючі тканини організму руйнуються, порушується робота органів, погіршується стан організму загалом. Завдяки тому, що злоякісні клітини виділяють специфічні речовини, які руйнують стінку судини, стає можливим процес інтравазації - проникнення пухлинних клітин у кровоносне або лімфатичне русло [13]. 


\section{ВЕТЕРИНАРНА МЕДИЦИНА}

Певна частина вчених схиляється до думки, що доброякісні пухлини є першою стадією злоякісного пухлинного росту і за певних умов розвивається так звана «пухлинна прогресія» та перехід пухлини у злоякісний процес $[6,9]$. Прихильники цієї теорії вважають, що під впливом таких факторів, як тривалі механічні впливи, систематична дія подразнюючих хімічних речовин та вплив деяких фізичних чинників (наприклад, ультрафіолетове опромінення, висока чи низька температура, радіація) на доброякісні пухлини можуть сприяти перетворенню їх у злоякісні. Цей процес трансформації називається малігнізація, тривалість якої може коливатися від кількох місяців до двадцяти років і більше. Це залежить від морфологічних та клінічних особливостей розвитку пухлин у різних органах $\mathrm{i}$ тканинах $[9,18]$.

Існує ціла низка станів, які відносять до передракових процесів облігатного значення, i вони в подальшому майже завжди трансформуються у злоякісні пухлини. До передракових процесів облігатного значення можна віднести тривало існуючі дефекти шкіри і слизових оболонок, такі як виразки, папіломи, кератози [7, 12, 19].

Обмін речовин у пухлинних клітинах змінюється і набуває певних особливостей по мірі розвитку новоутворення. Спостерігається наростаюча білоксинтезуюча здатність і сповільнення розпаду білків у пухлинних клітинах. Паралельно зі збільшенням пухлини в ній все більше і більше змінюється біохімічне середовище. Відбувається порушення співвідношення й активності ферментів, змінюється склад нуклеїнових кислот та гідратація клітини $[5,18]$.

Проведення профілактики розвитку новоутворень у собак майже не можливо. Адже ніколи достеменно не можна визначити, які саме, зовнішні чи внутрішні чинники будуть викликати процес трансформації нормальної клітини організму в пухлинну. Одним з так званих «факторів ризику» виникнення пухлин $є$ вік. Загальновідомо, що у старих тварин, і собаки не виняток, новоутворення з'являються значно частіше, ніж у молодняку. Також доведена породна схильність собак до пухлин певних видів. Існує думка, що новоутворенням молочної залози у самок можна запобігати завдяки своєчасній стерилізації. У самців за рахунок кастрації можна уникнути пухлинних процесів у сім'яниках $[5,8,12,20]$.

У результаті проведених досліджень серед піддослідних тварин, що були поділені на дві групи, кращий терапевтичний ефект показав препарат «Вінкристин». У собак, до схеми лікування яких було включено «Вінкристин» спостерігалась позитивна тенденція вже після першої ін'єкції препарату. Після другої ін'єкції препарату були реєстровані видимі зменшення в об'ємі та «присихання» папілом. Через чотирнадцять днів після початку курсу хіміотерапії більшість папілом були зменшені, сухі; нові папіломи не утворювалися. Після третьої і четвертої ін'єкції «Вінкристину» в чотирьох дослідних тварин із п'яти констатували повне відторгнення папілом. У однієї собаки виявили декілька атрофованих папілом, які також у подальшому повністю відторглися.

У другій дослідній групі тварин результати були менш позитивними, що свідчить про низьку терапевтичну ефективність препарату «Фітоеліта Метастоп» як хіміотерапевтичного засобу. Через 10 днів після початку лікувальних заходів у двох собак, до схеми лікування яких було включено «Фітоеліта Метастоп», відмічали сповільнення росту папілом. Через місяць після початку лікування у вищезазначених собак папіломи були значно зменшені, але повністю не зникли. Ще у двох тварин з увєї дослідної групи навіть на 30-й день від початку хіміотерапії не було зареєстровано позитивної динаміки, клінічний стан тварин був аналогічним початковому. В однієї собаки, яку лікували за допомогою препарату «Фітоеліта Метастоп», навіть спостерігалося збільшення наявних і поява нових папілом.

\section{Висновок}

Патологія пухлинного росту в собак та кішок є досить поширеною проблемою. Серед собак 3 новоутвореннями 70 \% були породистими, а 30 \% безпорідні. Але достовірної схильності до пухлин певного виду в якоїсь окремої породи не виявляється. У собак найчастіше реєструють новоутворення молочної залози (21,4 \%), папіломатоз (18,4\%), ліпоми (12,2 \%), саркому $(8,2 \%)$, аденому простати $(7,1 \%)$, остеому $(6,1 \%)$, атерому $(5,1 \%)$, карциному $(5,1 \%)$, фіброму $(5,1 \%)$, гемангіому $(3 \%)$ та меланому (3 \%). Процес формування пухлини починається 3 порушення регенерації клітин, потім спостерігаються їх дисплазія та гіперплазія, а пізніше - малігнізація проліферуючих клітин та формування пухлинного зачатка. Необхідно досліджувати не лише саму пухлину, а й ступінь ураження та втягнення в патологічний процес оточуючих тканин, слідкувати за реакцією регіонарних лімфовузлів та за появою і розвитком метастазів. Як хіміотерапевтичний засіб рекомендовано застосовувати препарат «Вінкристин», який дає виражений терапевтичний ефект вже через 7-10 днів від початку курсу хіміотерапії. Папіломи 


\section{ВЕТЕРИНАРНА МЕДИЦИНА}

поступово зменшуються в розмірах, стають сухими та відбувається їх відторгнення.

Перспективи подальших досліджень полягають у розробці методів ранньої діагностики новоутворень шляхом визначення у крові тварин підвищеного вмісту Інтерлейкіну-6 та Інтерлейкіну-17, які пригнічують апоптоз, активують ангіогенез та проліферацію клітин у зоні патології тканинного росту.

\section{References}

1. Urbanovych, P. P., Pototskyi, M. K., Hevkan, I. I., Zon, H. A., Borysevych, B. V., Papchenko, I. V., Kryvutenko, O. I., Kotsiumbas, H. I., Khmil,Ye. P., Shkil, M. I., Zhyla, M. I., Lukashyk, H. V., Omelianenko M. M., Stronskyi, Yu. S., \& Dankovych, P. C. (2008). Patolohichna anatomiia tvaryn. Kyiv [In Ukrainian].

2. Crump, K., \& Thamm, D. H. (Eds.). (2011). Cancer Chemotherapy for the Veterinary Health Team. doi: $10.1002 / 9781118785621$.

3. Apatenko, A. K. (1977). Mezenhimnye i nejroektodermalnye opuholi i poroki razvitiya kozhi. Moskva: Medicina [In Russian].

4. Skrypka, M. V., Panikar, I. I., \& Kolych, N. B. (2012). Atlas patolohichnoi morfolohii tvaryn. Poltava [In Ukrainian].

5. Babaeva, A. G., \& Zotikov, E. A. (1987). Immunologiya processov adaptivnogo rosta, proliferacii i ih narusheniya. Moskva: Nauka [In Russian].

6. Palcev M. A., Ivanov A. A. (1995). Mezhkletochnye vzaimodejstviya. Moskva: Medicina [In Russian].

7. Pal'cev, M. A., Anichkov, N. M. (2005). Atlas patologii opuholej cheloveka: posobie dlja sistematicheskogo poslevuzovskogo professional'nogo obrazovanija vrachej. Moskva: Medicina [In Russian].

8. Soroka, N. M., \& Pashkevych, I. Yu. (2008). Etiolohichni aspekty transmisyvnoi venerychnoi sarkomy sobak. Naukovuj Visnyk Natsionalnoho Ahrarnoho Universytetu, 127, 282-284 [In Ukrainian].

9. Baranov, S. V. (1991). Diagnostika opuholej u sobak, Veterinarija, 6, 66-68 [In Russian].

10. Soroka, N. M., \& Pashkevych, I. Yu. (2010). Osoblyvosti morfolohichnoi budovy transmisyvnoi venerychnoi sarkomy sobak. Veterynarna Medytsyna Ukrainy, 11, 18-20 284 [In Ukrainian].

11. Napalkov, N. P. (2004). Rak i demograficheskij perehod. Voprosy Onkologii, 50 (2), 127-130 [In Russian].

12. Anichkov, N. M. (1988). O patogeneze opuholevogo processa. Arhiv Patologii, 1, 3-11 [In Russian].

13. Zaviryuha, V. I., Sayevich, V. I., \& Misak, A. R. (1999). Onkologichni hvorobi tvarin i metodi likuvannya. Naukovuj visnik LDAVM im. S. Z. Gzhickogo, 2, 56-63 [In Ukrainian].

14. Breli, Dzh., Bostok, D. E., \& Dennis, R. (2003). Onkologicheskie zabolevaniya melkih domashnih zhivotnyh. Moskva: Akvarium LTD [In Russian].

15. Ponomarkov, V. I., Ratto, A., Capurro, S., \& Rossi, N. (1993). Voprosy Onkologii, 39 (7-12), 259268 [In Russian].

16. Terehov, P. F. (1983). Veterinarnaya klinicheskaya onkologiya. Moskva: Kolos [In Russian].

17. Mazurkevych, A. Y., Urbanovych, P. P., \& Kotsiumbas, H. I. (2008) Patolohichna fiziolohiia $i$ patolohichna anatomiia. Kyiv [In Ukrainian].

18. Zubova, S. G., \& Okulov, V. B. (2001). Molekuljarnye mehanizmy dejstvija faktora nekroza opuholej A i transformirujushhego faktora rosta R v processe otveta makrofagana aktivaciju. Immunologija, 5, 18-22 [In Russian].

19. Adaskevich, V. P. (2000). Aktualnaya dermatologiya. Nizhnij Novgorod. Iz-vo NGMA [In Russian].

20. Klopfleisch, R. (Ed.). (2016). Veterinary Oncology. doi: 10.1007/978-3-319-41124-8.

21. Prudnikov, V. S., Karasyov, N. F., \& Birman, B. Ya. (2000). Bolezni sobak i koshek: prakticheskoe posobie. Minsk: Polibig [In Russian].

Стаття надійшла до редакції 20.04.2020 р.

Бібліографічний опис для цитування:

Дмитренко Н. І., Шерстюк Л. М. Поширеність та лікування патології тканинного росту в собак. Вісник ПДАА. 2020. № 2. С. 179-186.

(C) Дмитренко Надія Іванівна, Шерстюк Любов Миколаївна, 2020 